\title{
Physical Analysis of Hail Fall Risk in Iran and the Consequent Damages on Agricultural Crops
}

\author{
Javad Bodagh Jamli1,2 \\ ${ }^{1}$ Faculty Member of University of Environment, Karaj, Iran \\ ${ }^{2}$ Atmospheric Science and Meteorological Research Center (ASMERC), Tehran, Iran \\ Email: jbjamali@gmail.com \\ Received 25 October 2014; revised 28 November 2014; accepted 15 December 2014 \\ Copyright (C) 2014 by author and Scientific Research Publishing Inc. \\ This work is licensed under the Creative Commons Attribution International License (CC BY). \\ http://creativecommons.org/licenses/by/4.0/

(c) (i) Open Access

\section{Abstract}

Hail is a meteorological phenomenon that directly concerns to agricultural sector in Iran. Hailstorms affect crop yield that depends on the crop species and the phonological time. In this investigation, climatological study of hail fall has been performed through the available dataset in 118 synoptic stations across the country during a period of 20 years (1985-2004) and hail event map was drawn. After analyzing the data and considering the produced maps, regarding the number of hail occurrence in the country, the following provinces respectively illustrate the highest annual mean of hail fall; Chaharmahal-e-bakhtiari, Ilam, Tehran and Kurdistan (about 4 times/yearly). In the next step, using the statistics of the agricultural insurance affairs during 1995-2005, cultivation areas damaged by hail fall in the farms of agricultural strategic products including; irrigated and rain fed wheat, grain, rice, cotton, sugar beet and potato have been studied, and then the classified maps of hail damage have been plotted for each province and crop. The produced maps indicate that most of the damaged area by hail fall has been related to irrigated wheat crop, with an annual average of $\mathbf{1 2 6 9 0 . 8}$ hectares in the whole country, then the damaged crops were ordered respectively as following: rain fed wheat, sugar beet, potato, grain, cotton and rice.

\section{Keywords}

Hail Fall, Meteorological Phenomenon, Hail Damages, Agricultural Crops, Iran

\section{Introduction}

According to the documentary analyses of international credible scientific centers at the end of twentieth century, natural disasters are the most usual forms of disasters in the world. Not only the disasters are increasing in quan- 
tity, but also the affected populations and the economic damages have been increasing considerably during the three recent decades. The damages of disasters will be decreased, by an accurate decision and planning.

Among the various meteorological risks, hail is certainly one of the less studied, measured and forecasted risks. This is due to the extremely high spatial temporal variability of the phenomenon as well as the complexity of the microphysical and kinematical processes that are involved. Whiles, the economic consequences of hail storms can be devastating in different sectors such as agriculture, aviation, transportation, urbanization and etc. [1].

The study of hailstorms is based on several meteorological parameters that are involved in conditions required to produce convection (temperature, instability, a deep humid layer in the low and middle troposphere and an updraft to initiate convection), as well as on the specific topographic characteristics of the geographical area studied [2]-[6].

This meteorological phenomenon variously affects the different climatic regions of the world. In regard of hailstorm formation mechanism, there are two restrictive factors in too warm or too cold climates. One factor is warm air masses aloft in too warm climate, the other one is lack of convection required for the triggering of hail generating in cumulonimbus clouds. Hence, only a small portion of the Earth's surface is significantly affected by this phenomenon, namely the middle latitude regions (between about $30^{\circ}$ and $50^{\circ}$ ), related to the average position of the upper level jet and close to mountain areas [7].

According to Lopez et al. (2007) [5], the correlation of the occurrence of hail events with climatic variables is a complicated problem because of the small area disturbed and because of the short time associated with hail events. Thus, although economic losses related to hail can be very important, the information on the climatology associated with hail events is very limited. It must also be recognized that most of the records of hailstorm events are made for insurance purposes.

A. Saa Requejo et al. (2011) [8] developed a work to test the correlation between average minimum temperatures and hail damage intensity over the Spanish Iberian Peninsula. The obtained results did not confirm the results previously obtained for France and the Netherlands that relate observed hail damage to the average minimum temperature.

López et al. (2007) [5] demonstrated that a reliable hailstorm study must include an adequate selection of meteorological variables that must depend on the specific geographical areas involved. Also, a model which is appropriate for a specific geographical area may not give satisfactory results for other areas [9] [10].

Greene and Clark (1972) [11] stated that more intense radar returns caused by hailstones aloft could lead to vertically integrated liquid (VIL) values in excess of those calculated in the absence of hailstones. They noted this VIL discrepancy could be used as a means of assessing the severity of storms.

Edwards and Thompson (1998) [12] investigated the usefulness of VIL in predicting hail severity. Though they found that large hail is not likely to be associated with low VIL values, they also showed high VIL values do not guarantee large surface hail fall.

McMaster (1999) [13] evaluated the magnitude of hail damage to winter crops in Australia as the result of climate change in two geographical areas of New South Wales. The author used upper-air climatic data from a global climatic model to obtain forecasts of hail damage. For both geographical areas studied, the author found no change in hail-related crop damage losses in relation to the changes in climatic indicators that resulted from climatic change. Mills (2005) [14] mentioned that the losses due to damage caused by natural disasters have increased since 1960. This increase has been produced in part by socioeconomic and demographic trends. These trends may be considered when forecasting extreme climate events, mainly for insurance purposes. Specifically, Mills et al. (2002) [15] found a positively relation between lightning related insurance losses and average temperature in the USA.

Iran is a country in the Middle East with various local climates and geographic features that sometimes has been subjected to hail precipitation in local scale and in consequence, experienced a wide range of damages in different sectors. For example; the hail fall caused some devastative damages by flood rising and losses in agriculture (especially damages on fruit gardens) in Isfahan Province on 20 April 2003. This event lasted about 20 - 25 minutes and the hailstones weight estimated between $0.004-0.02 \mathrm{~kg}$. Another case happened through sever hail falling and a sudden temperature reduction, which led to a losses around $\$ 3$ million in agricultural sector in Miyaneh city (Northwest of Iran) in 2006 (based on the reports from Iranian Jehad-Agriculture ministry). 


\section{Materials and Methods}

In this study, long-term data of hail occurrence have been gathered from 118 synoptic stations of Islamic Republic of Iran Meteorological Organization (IRIMO) and different vulnerable areas have been categorized based on hail damages (Figure 1).

Using damage datasets related to hail occurrence in agricultural sector, related damages have been estimated and analyzed based on cultivation area, then the hail damage map have been drawn too.

\section{Zoning and Climatic Analysis for Hail Precipitation}

Precipitation possibility in the wide spectrum of forms such as rain, snow, drizzle, and hail is dependent on essential thermodynamic condition according to instability condition of temperature and moisture in atmosphere and other factors.

Since, hail is one of the kinds of natural hazards, studying spatial and temporal distribution of this phenomenon is necessary, thus the climatologic analysis of hail has been carried out in this study. Considering the importance of hail fall and originated damages in Iran, the zoning of hail events on all regions/provinces of the country has been presented. Hail occurrence has been recorded in synoptic stations of the IRIMO which are regarded as credible references in this investigation. As known hail occurrences in the IRIMO synoptic stations have been recorded as synoptic codes according to WMO guideline. In these codes, the whole meteorological factors and related phenomena have been recorded with regard to kind, amount and severity.

These codes consisting of several groups and the $7^{\text {th }}$ group (WW or present weather) has a chart with 100 codes, which are recording and issuing 3 hourly including 00, 03, 06, 09, 12, 15, 18, 21 UTC by observers, so no phenomenon has been disregarded. The 99, 27, 87, 90, 93, 94, 96 codes have been used for the data relating to hail, consisting of different kinds of hail with different intensity.

IRIMO observation network consists of wide spectrum of stations with special duties such as; synoptic, climatology, rain-gauge, radiation, evaporation, agricultural meteorology, aeronautical meteorology, and upper atmosphere stations which are almost 4600 stations sited in the country. Among total different stations, 298 stations are the main synoptic stations (which are reporting all meteorological parameters 3 hourly).

Regarding, necessity of the long term statistical data for more precise analysis of hail fall, using the stations which have at least 20 years statistics, therefore 118 synoptic stations have been selected as shown in Figure 1. At first, annual hail precipitation events have been calculated from 3 hourly data series then the mean values have been extracted during the study period for each station. Because the main purpose of this study is determining the hail prone areas and evaluating the resulted damages, we ignore to describe statistical method using for data analysis.

For categorizing the areas prone to hail, Table 1 has been used for drawing hail risk map in the country.

\section{Results}

\subsection{Climatological Analysis of Hail Falls over Iran}

According to the gathered data which were illustrated in the previous part, average of hail occurrence at the reference station in all provinces (stations with maximum occurrence in province) have been calculated. The reference station in each province is the station having the maximum long-term average of hail occurrence.

Province categorization in viewpoint of hail fall is based on the number of hail occurrence at the reference stations. Moreover, the stations which are considerable regarding hail occurrence (regarding hail severity, temporal length and occurrence number) have been noticed and used in data analysis too.

Figure 2 shows the annual average of number of days accompanying with hail at the selected stations in all 30 provinces of Iran.

Based on the severity categorization of the hail occurrence as shown in Table 1, different provinces in the country have been categorized according to the number of hail occurrence (Figure 3).

Regarding Figure 3 that demonstrated the hail risk categorization in all provinces, the following results are obtained:

(1) All provinces in Iran are subjected to this phenomenon (hail fall);

(2) Occurrence of this phenomenon has been increasing in some of stations and has been decreasing in other stations (based on the record of study related to hail damages); 


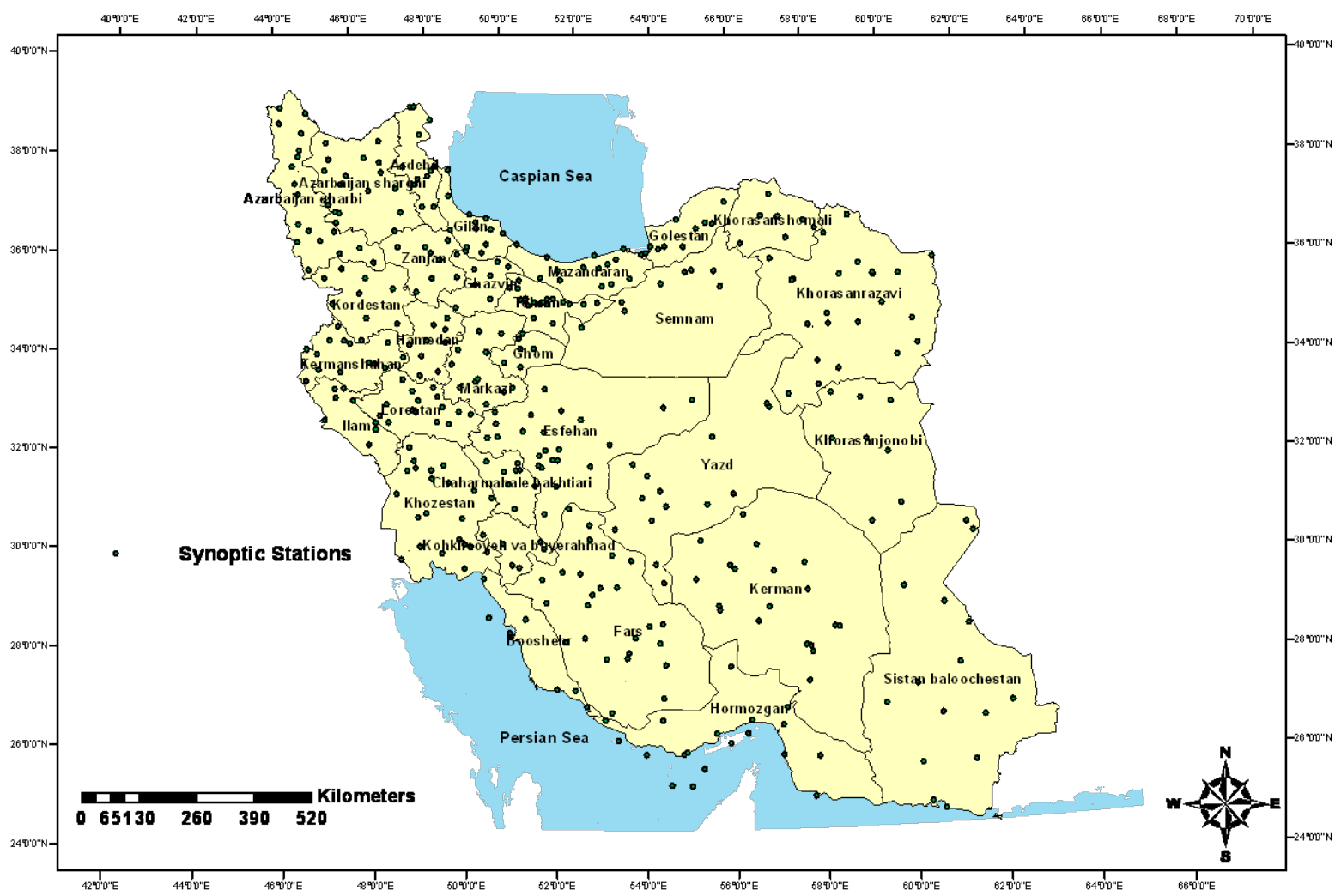

Figure 1. Geographical distribution of 118 synoptic stations in Iran.

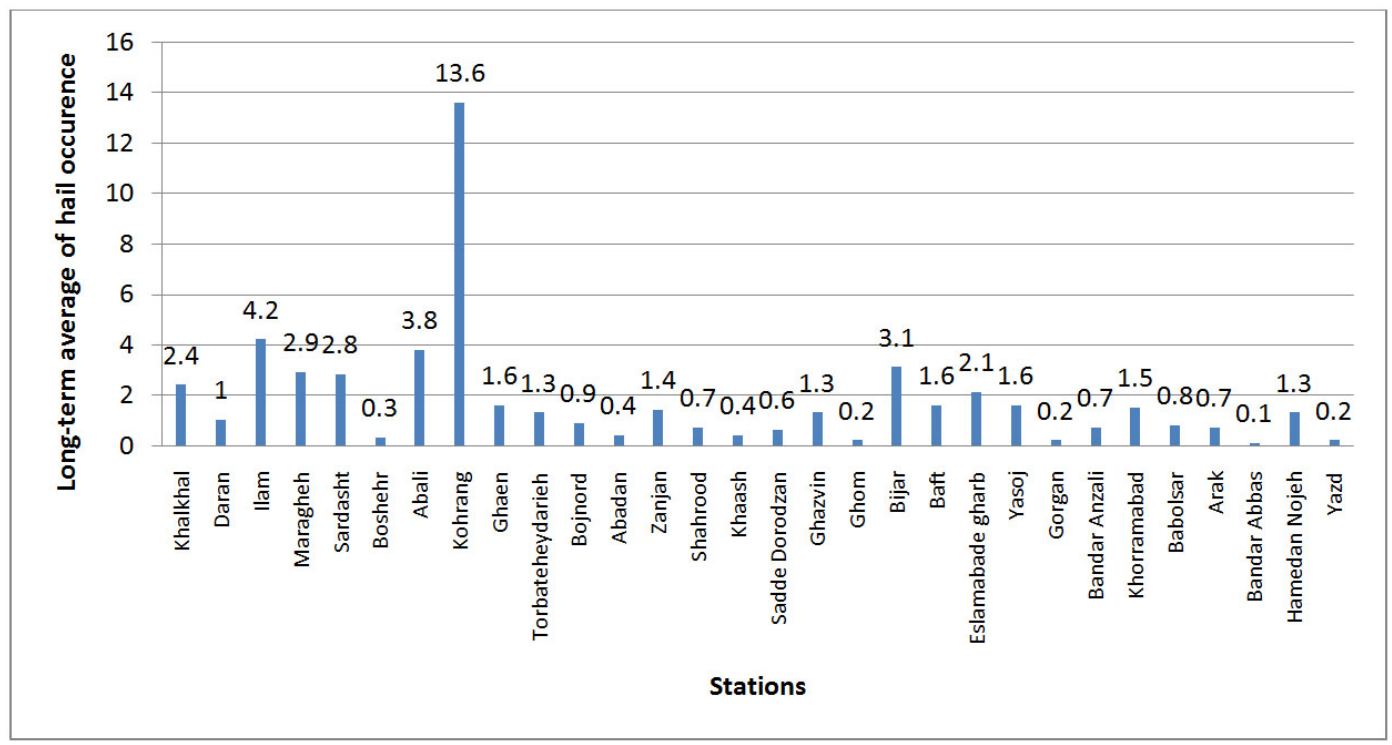

Figure 2. Annual average of number of days accompanying with hail at the 30 reference stations over 1985-2005.

Table 1. Basic severity categorization of the hail occurrence (based on the number of days).

\begin{tabular}{cccccc} 
Category index & Weak & Scarce & Moderate & Strong \\
\hline Annual average of hail occurrence & $<0.5$ & $0.5-1$ & $1-2$ & $2-3$ \\
\hline
\end{tabular}




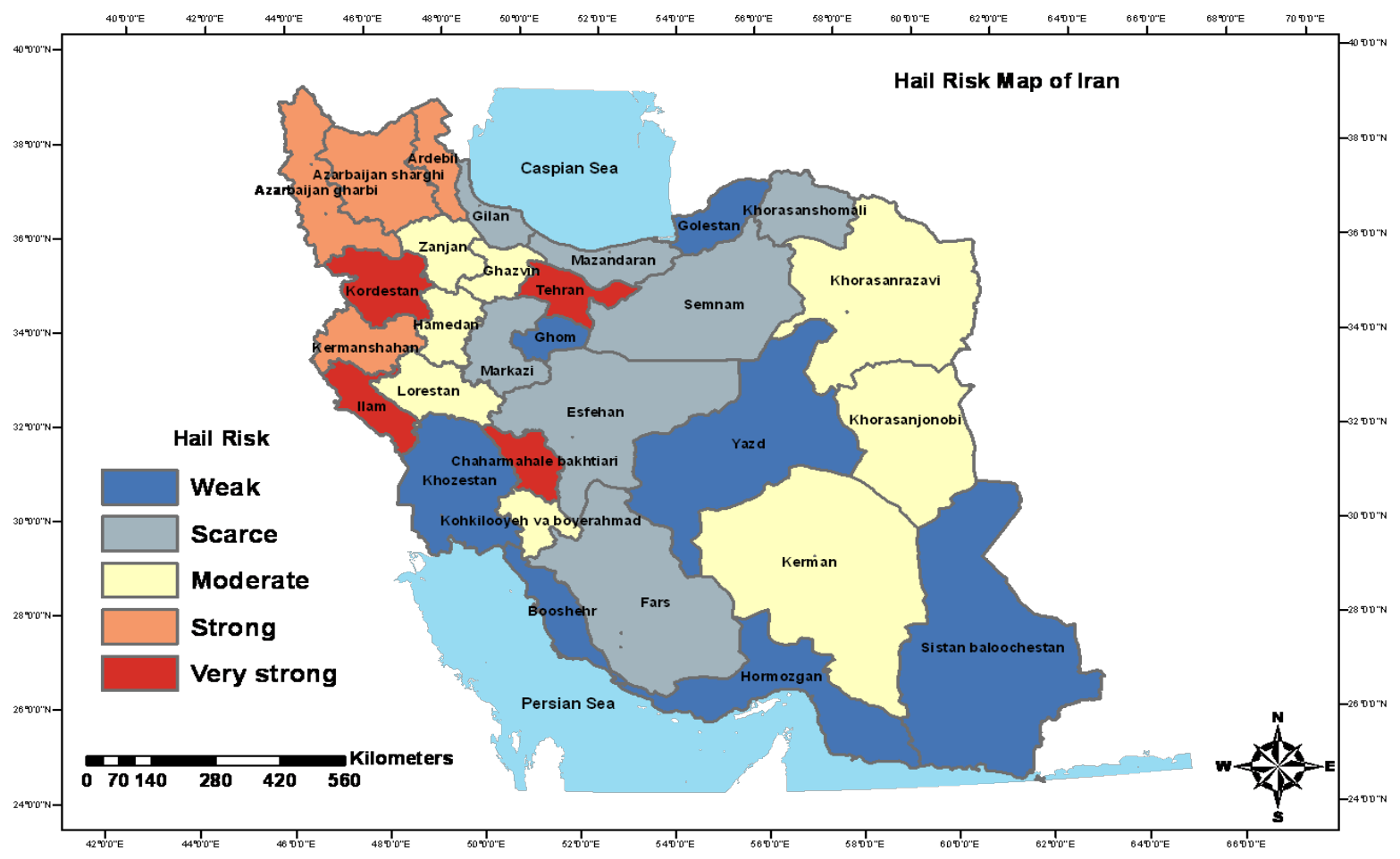

Figure 3. Hail risk categorization in 30 provinces of Iran.

(3) Hail risk intensity in Chaharmahal-e-Bakhtiyari, Ilam, Tehran, and Kordrstan provinces is higher than other provinces;

(4) Ardebil, Kermanshah, Azarbayejan-e-Gharbi and Azarbayejan-e-Sharghiprovinces are categorized in the second intensity class regarding the hail occurrence;

(5) Hail risk intensity are moderate in Zanjan, Ghazvin, Hamedan, Lorestan, Kohgilouieh and Boyerahmad, Khorasan-e-Razavi, Khorasan-e-Shomali and Kerman provinces;

(6) Hail risk is characterized weak in other provinces.

Regarding the existing differences in geographical distribution of hail occurrence over the country regions, the causes are related to the local climates as well as the topographical features of the areas, as the mountainous and high lands in center, west and northwest of the country characterized to more risky class of hail fall.

\subsection{Zoning and Analysis of Hail Damages}

\subsubsection{Average of the Cultivation Area Damaged by Hail Fall According to the Provinces and the Crops}

In this part, hail damages on the cultivation areas of fundamental and strategic products such as irrigated and dry farming wheat, grain, sugar beet, rice, cotton and potato have been investigated using statistics available in agricultural insurance affairs. According to a survey in damages data of agricultural insurance affairs, the following restrictions have been found;

(1) The received data/records are in manual print format and they are not in electronic file and data base;

(2) The data/records are available in a short period from1995 to 2005;

(3) The products are mainly agricultural, so continuous and credible statistics of damages to the garden products are not available.

Among the agricultural crops according to the length and continuity of statistics and also their strategic importance for the country, seven kinds of crops have been selected including irrigated and dry farming wheat, rice, potato, sugar beet and cotton.

One important detected weakness in these statistics is that no matching of statistics into exact geographical 
position of damage occurrence in the province, whereas IRIMO data base statistics in station-based and for each county had been received.

In order to calculation, it was needed firstly the statistics received from insurance affairs, to be modified to the electronic version. So they finally imputed to PC (personal computer) and the analysis has been continued using softwares.

According to the available statistics for observed products the most damaged cultivating area is related to the irrigated wheat with the annually mean of 12,690/8 hectare for the whole country, then respectively dry farming wheat (11,383/8 ha), sugar beet (4152/2 ha), potato (1662/7 ha), grain (1590/9 ha), cotton (973/7 ha) and rice (275/3 ha).

In a provincial outlook, the following conclusion in view of the most damaged cultivation surface for different crops of the provinces has been obtained as shown in Table 2.

According to Table 2, the most annual mean of damaged cultivation surface for potato products is related to Azarbayejan-e-sharghi and Hamedan provinces about 1344/6 ha, 150/2 ha respectively. For the other crops the classification of provinces in regard of the most damaged cultivation area are as following;

For rice products, Khouzestan province with annual mean of damaged cultivating surface of 175/2 ha, and Fars province with annual damaged surface of 41/2 ha.

For cotton products, the annual mean of damaged cultivation surface in Khorasane-e-razaviand Fars provinces are about 320/5ha and 176/2 ha respectively.

For Sugar beet products, Khorasane-e-razavi province got the annual mean of damaged cultivation surface of 1426/8 ha and afterward Azarbayejane-e-gharbishoweda damaged surface of 1271/3 ha.

About grain (irrigated) products, Khorasane-e-razaviand Khorasane-e-shomali provinces had the annual mean of damaged cultivation surface of 643/6 ha and 160/9 ha respectively.

For wheat (dry farming) products, Azarbayejan-e-gharbiand Kordestan provinces had annual mean of damaged cultivation surface of 1943/6 ha and 1872/2 ha respectively.

For wheat (irrigated) products, Kerman province with an annual mean of damaged cultivation surface of 2451/2 ha was in first, and the second one was Khorasan-e-razavi province that had 1789/9 ha of damaged surface.

For example Figure 4 shows the mean amount of damaged cultivation area in all provinces for cotton products.

\subsubsection{Categorization of the Provinces Based on the Damaged Cultivation Areas}

According to the above mentioned results, all provinces have been classified based on the cultivation areas damaged due to hail fall during 1995-2005for some agricultural crops such as: potato, rice, cotton, sugar beet, grain and irrigated and dry farming wheat has been shown in Figures 5-7.

Among all of the above considered agricultural crops, the most damaged cultivation surface during 10 years (1995-2005) is related to irrigated wheat with annual mean of damaged cultivation surface about 12,690/8 hectare and afterward dry farming wheat, sugar beet, potato, grain, cotton and rice products are ordered respectively.

For the provinces the most damaged area by hail is related to the different crops as shown in Figures 5-7 are as following:

Azarbayejan-e-sharghi province: The most damaged surface of potato;

Khouzestan province: The most damaged surface of rice;

Khorasan-e-razavi province: The most damaged surface of cotton;

Khorasan-e-razavi and Azarbayejan-e-gharbiprovinces: The most damaged surface of sugar beet;

Khorasan-e-razavi, Khorasan-e-shomali, Isfahan and Markazi provinces: The most damaged surface of grain;

Azarbayejan-e-gharbi, Zanjan and Kordestan provinces: The most damaged surface of dry farming wheat;

Kerman province: The most damaged surface of irrigated wheat.

\section{Discussion and Conclusion}

The risk management is defined as: The systematic process of using administrative directives, organizations, and operational skills and capacities to implement strategies, policies and improved coping capacities in order to lessen the adverse impacts of hazards and the possibility of disaster (UNISDR ${ }^{1}$ ). Past damages statistics as well as the most recent technologies are very important for recognizing the magnitude of risk.

${ }^{1}$ The United Nations Office for Disaster Risk Reduction. 
Table 2. Damaged cultivation area related to the crop-kinds in vulnerable provinces.

\begin{tabular}{ccc}
\hline Crops & Provinces & Damaged Surface in Hectare \\
\hline Irrigated Wheat & Kerman & $2451 / 2$ \\
& Khorasan-e-razavi & $1789 / 9$ \\
Dry Farming Wheat & Azarbayejan-e-gharbi & $1943 / 6$ \\
& Kordestan & $1872 / 2$ \\
Sugar Beet & Khorasane-e-razavi & $1426 / 8$ \\
& Azarbayejane-e-gharbi & $1271 / 3$ \\
Potato & Azarbayejan-e-sharghi & $1344 / 6$ \\
& Hamedan & $150 / 2$ \\
Grain & Khorasane-e-razavi & $643 / 6$ \\
& Khorasane-e-shomali & $160 / 9$ \\
Cotton & Khorasane-e-razavi & $320 / 5$ \\
& Fars & $176 / 2$ \\
Rice & Khouzestan & $175 / 2$ \\
& Fars & $41 / 2$ \\
\hline
\end{tabular}

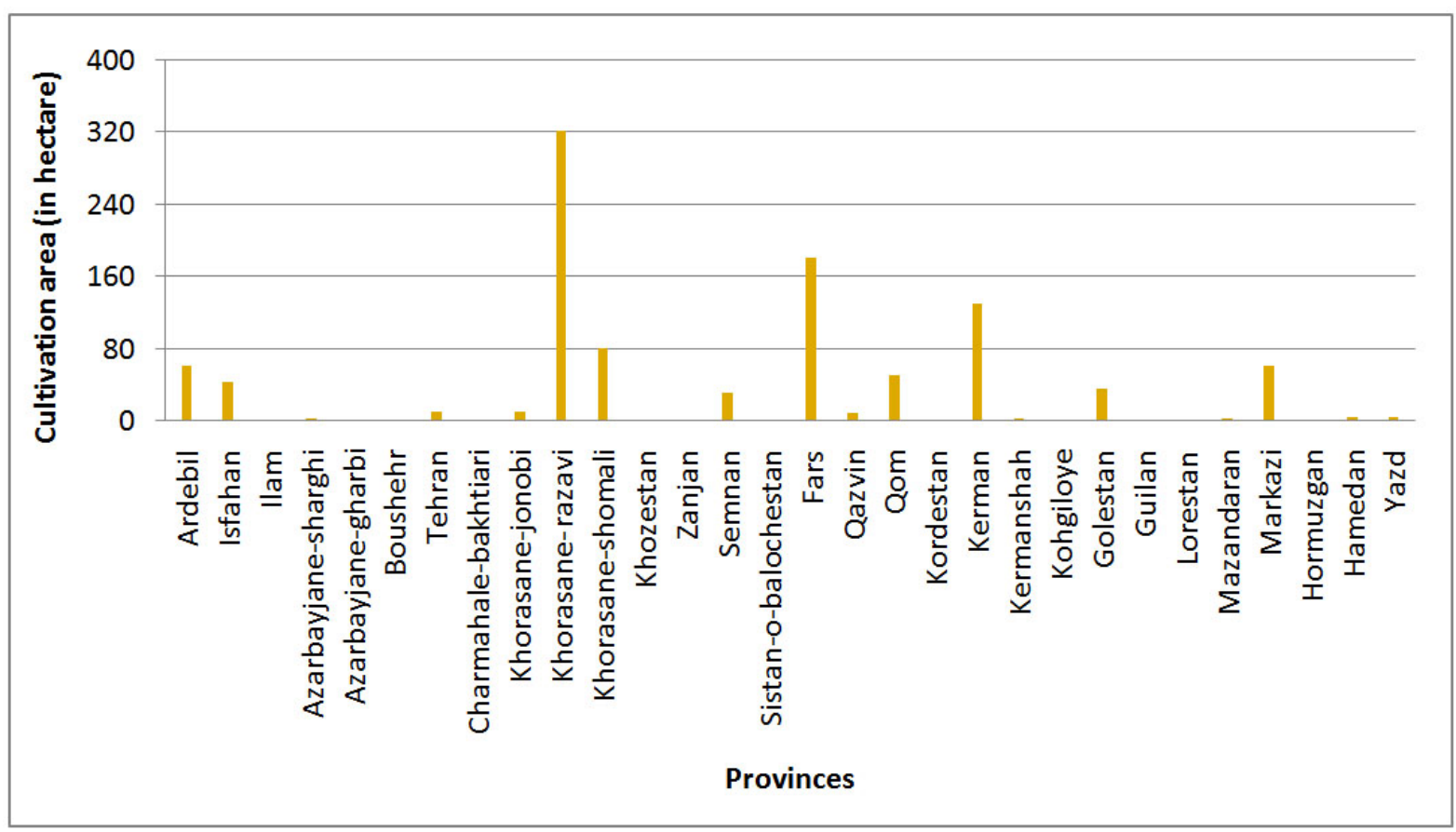

Figure 4. Average of the area under cotton cultivation damaged by hail fall in the provinces during 1995-2005.

Analysis process is one of the current methods in solving questionable problems, having knowledge concerning dispersion and extension of the catastrophic damages is a fundamental facture in risk/disaster management. For example, recorded statistics and operational methods can illustrate extent, magnitude and occurrence period of a disaster. This kind of information could help involved organizations to work in an integrated framework.

Natural disasters are increasing parallel to their impacts originated from external causes such as population grows and urbanization development in risky areas. 

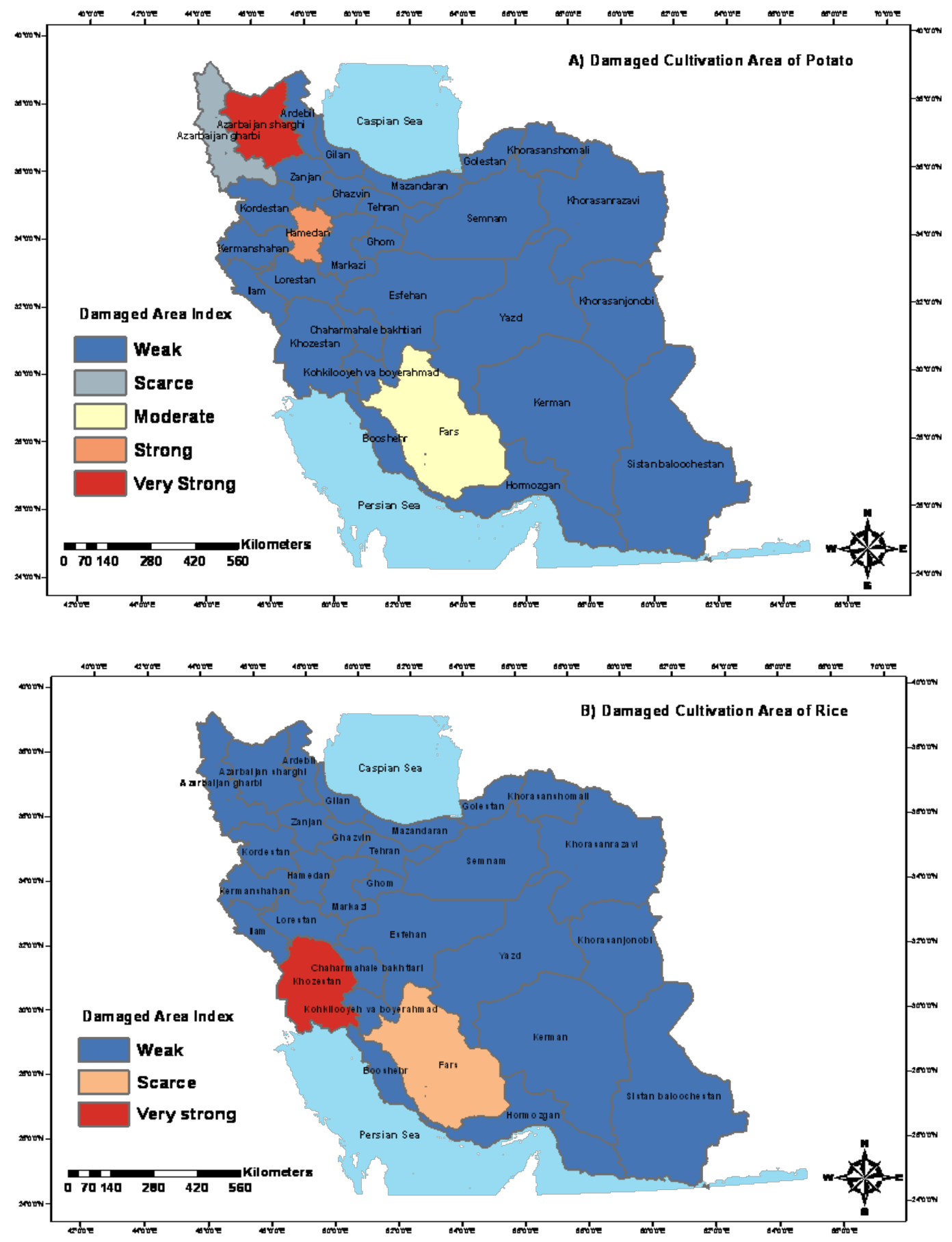

Figure 5. Categorization of the provinces based on the damaged area by hail fall for 1995-2005. A) Cultivation area of potato; B) Cultivation area of rice.

Earthquakes, hurricanes, rainstorm which are natural phenomena considered as hazards, whiles these phenomena solely and apart from social condition and biosphere are not considered disasters. For example, when earthquake happens in desert area there is not any resulted risks due to lack of urbanization/human kind. In addition to hazards, it should be in mind another concept considered vulnerability which is related to the consequences of physical, social, economical and environmental conditions which show the community ability to meet 


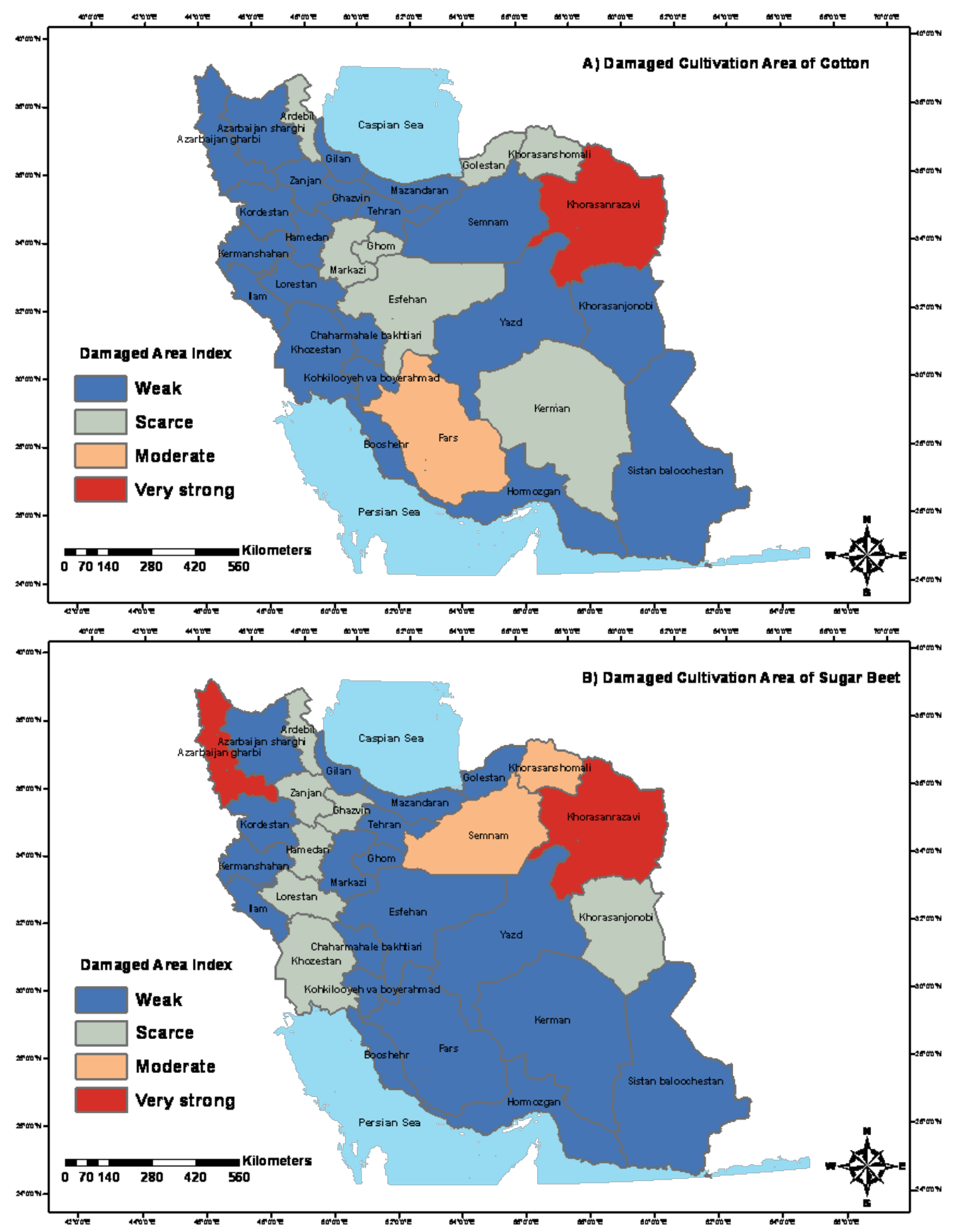

Figure 6. Categorization of the provinces based on the damaged area by hail fall (1995-2005). A) Cultivation of area of cotton; and B) Cultivation of area of sugar beet.

the resulted damages of disasters. Exposure condition is another factor of natural disaster risk, which is referred to human property, damaged by the hazards.

Generally, risk means the amount/magnitude of expected damages (death, goods and life damages, etc.) which is produced by hazards. Disaster risk is a function of hazard, exposure condition and vulnerability that is defined as following forms:

Disaster Risk $=$ Function (Hazard, Exposure, Vulnerability)

Increasing of exposure condition and delay in decreasing risk, result in growth in amount of natural disaster and more widespread damages. According to Figure 8, disaster risk is an interaction between hazard, vulnerability and 


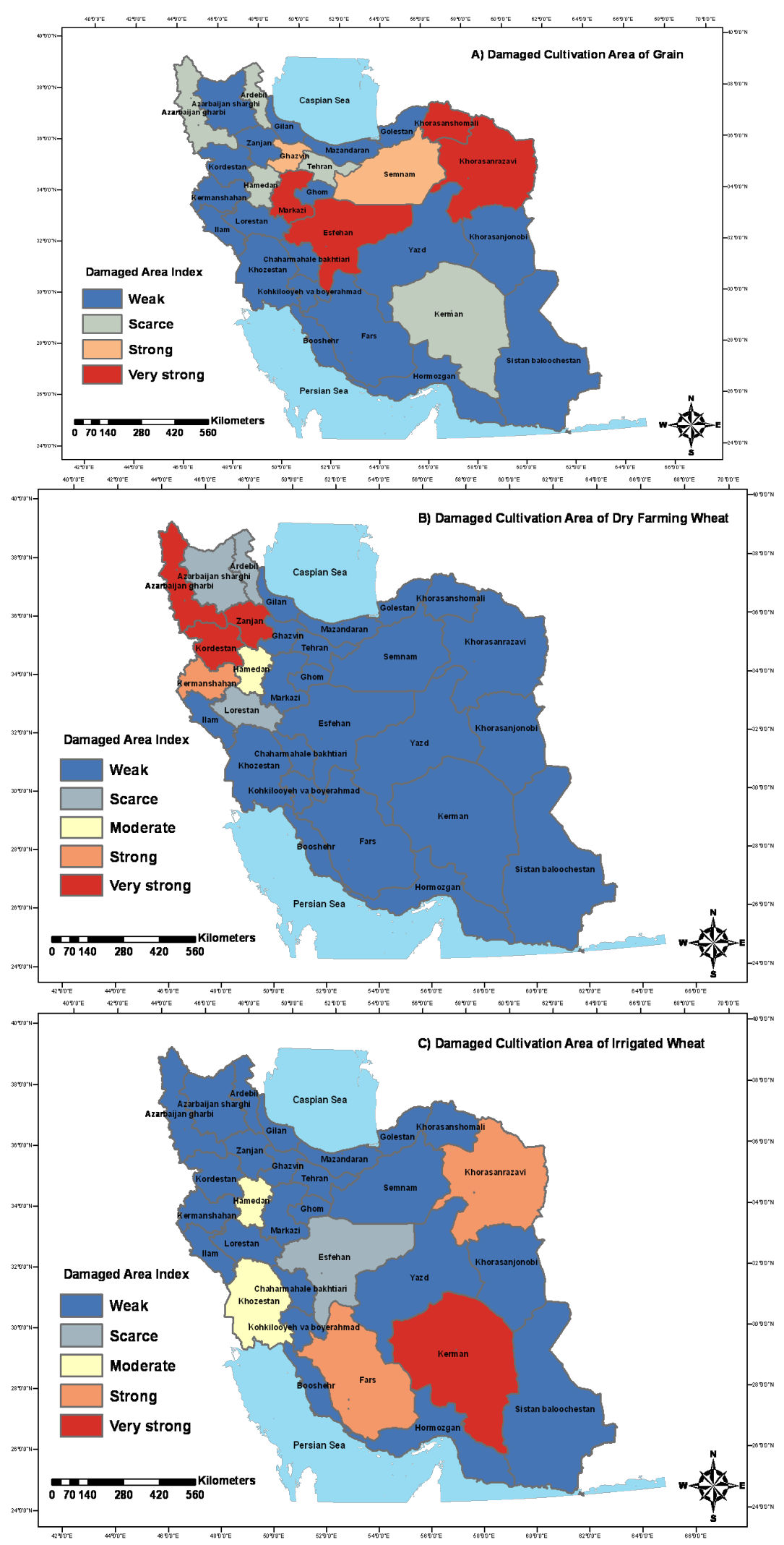

Figure 7. Categorization of the provinces based on the damaged area by hail fall (1995-2005). A) Cultivation area of grain; B) Cultivation area of dry farming wheat; and C) Cultivation area of irrigated wheat. 


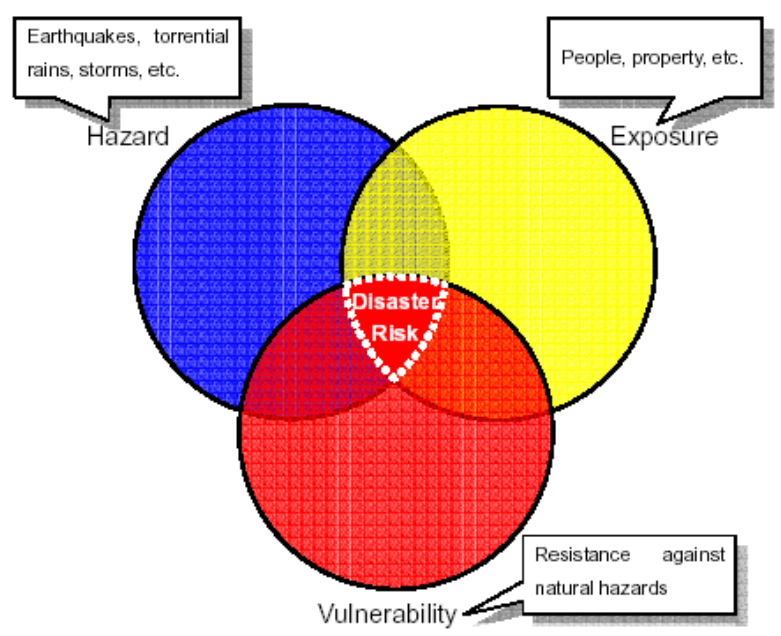

Figure 8. Conceptual schematic of relations between Hazard, Exposure and Vulnerability in natural disaster crises.

exposure condition included as joint parts of tree circles that is shown as a triangle.

If we want to decrease disaster risk and enlarge the level of security in the society, the dimensions of triangle should be lessened. Firstly, it should be considered that occurrence of natural disaster such as storm, hail, drought, and earthquake are not controllable and no serious action have been done to prevent them but these phenomena are predictable and feasible to early warning for society. Surely, in some cases such as hail and frost in agricultural part, there are limited possibilities to decrease damages. To change the rate of vulnerability, we can think about society resisting versus natural disasters. Another element which is controllable and manageable is that setting the situation away from exposure hazard and then decreasing the dimensions of the triangle presented in Figure 8.

For decreasing disaster risk, it is important to decrease the degree of vulnerability and exposure situations by getting aware of the environmental, economic and social conditions of hazard occurrence area.

As abovementioned, since risk recognition is one of the steps of risk management process, in this paper firstly a climatological study of hail has been performed in the country and then hail zoning maps to identify the risk of hail are produced.

As the derived results show, all provinces of Iran based on the long term statistics have probability of hail falling, whiles among them some provinces such as Charmahal-e-bakhtiari, Ilam, Azarbaijan-e-sharghi, Kurdistan and Ardebil, indicated more annual occurrence of hail. In regard of vulnerability of the agricultural sector, identifying and analyzing the damages resulted by hail as another step of risk management has been studied. In fact, regarding the International Strategic Standard for Disaster Reduction (ISDR), it is attempted to establish a database and perform hail risk map and vulnerability zoning of hail fall in the country.

\section{References}

[1] Tabary, P., Berthet, C., Dupuy, P., Figueras, J., Fradon, B., Georgis, J.F., Hogan, R., Kabeche, F. and Wasselin, J.P. (2010) Hail Detection and Quantification with C-Band Polarimetric Radars: Results from a Two-Year Objective Comparison against Hailpads in the South of France. 6th European Conference on Radar in Meteorology and Hydrology: Adv. in Radar Technology, Sibiu, 6-10 September 2010.

[2] Dessens, J. (1995) Severe Convective Weather in the Context of a Night Time Global Warming. Geophysical Research Letters, 22, 1241-1244. http://dx.doi.org/10.1029/95GL00952

[3] Johns, R.H. and Doswell III, C.A. (1992) Severe Local Storms Forecasting. Weather Forecast, 7, 588-612. http://dx.doi.org/10.1175/1520-0434(1992)007<0588:SLSF>2.0.CO;2

[4] Simeonov, P. and Giorgiev, C.G. (2003) Severe Wind/Hail Storms over Bulgaria in 1999-2001 Period: Synoptic- and Meso-Scale Factors for Generation. Atmospheric Research, 67-68, 629-643. http://dx.doi.org/10.1016/S0169-8095(03)00077-2

[5] López, L., García-Ortega, E. and Sánchez, J.L. (2007) A Short Term Forecast Model for Hail. Atmospheric Research, 83, 176-184. http://dx.doi.org/10.1016/j.atmosres.2005.10.014 
[6] García-Ortega, E., Fita, L., Romero, R., López, L., Ramis, C. and Sánchez, J.L. (2007) Numerical Simulation and Sensitivity Study of a Severe Hailstorm in Northeast Spain. Atmospheric Research, 83, 225-241. http://dx.doi.org/10.1016/j.atmosres.2005.08.004

[7] Eccel, E., Cau, P., Riemann-Campe, K. and Biasioli, F. (2010) Quantitative Hail Monitoring in an Alpine Area: 35Year Climatology and Links with Atmospheric Variables. International Journal of Climatology, 32, 503-517. http://dx.doi.org/10.1002/joc.2291

[8] Saa Requejo, A., García Moreno, R., Díaz Alvarez, M.C., Burgaz, F. and Tarquis, M. (2011) Analysis of Hail Damages and Temperature Series for Peninsular Spain. Natural Hazards and Earth System Sciences, 11, 3415-3422. http://dx.doi.org/10.5194/nhess-11-3415-2011

[9] Lynn, B.H., Druyan, L., Hogrefe, C., Dudhia, J., Rosenzweig, C., Goldberg, R., Rind, D., Healy, R., Rosenthal, J. and Kinney, P. (2004) Sensitivity of Present and Future Surface Temperatures to Precipitation Characteristics. Climatic Change, 28, 53-65. http://dx.doi.org/10.3354/cr028053

[10] Changnon, D. and Bigley, R. (2005) Fluctuations in US Freezing Rain Days. Climatic Change, 69, $229-244$. http://dx.doi.org/10.1007/s10584-005-3585-8

[11] Greene, D.R. and Clark, R.A. (1972) Vertically Integrated Liquid Water-A New Analysis Tool. Monthly Weather Review, 100, 548-552. http://dx.doi.org/10.1175/1520-0493(1972)100<0548:VILWNA>2.3.CO;2

[12] Edwards, R. and Thompson, R.L. (1998) Nationwide Comparisons of Hail Size with WSR-88D Vertically Integrated Liquid Water and Derived Thermodynamic Sounding Data. Weather and Forecasting, 13, 277-285. http://dx.doi.org/10.1175/1520-0434(1998)013<0277:NCOHSW>2.0.CO;2

[13] McMaster, H.J. (1999) The Potential Impact of Global Warming on Hail Losses to Winter Cereal Crops in New Southwales. Climatic Change, 43, 455-476. http://dx.doi.org/10.1023/A:1005475717321

[14] Mills, E. (2005) Insurance in a Climate of Change. Science, 5737, 1040-1044. http://dx.doi.org/10.1126/science.1112121

[15] Mills, E., Lecomte, E. and Peara, A. (2002) Insurance in the Greenhouse. Journal of Insurance Regulation, 21, 43-78. 
Scientific Research Publishing (SCIRP) is one of the largest Open Access journal publishers. It is currently publishing more than 200 open access, online, peer-reviewed journals covering a wide range of academic disciplines. SCIRP serves the worldwide academic communities and contributes to the progress and application of science with its publication.

Other selected journals from SCIRP are listed as below. Submit your manuscript to us via either submit@scirp.org or Online Submission Portal.
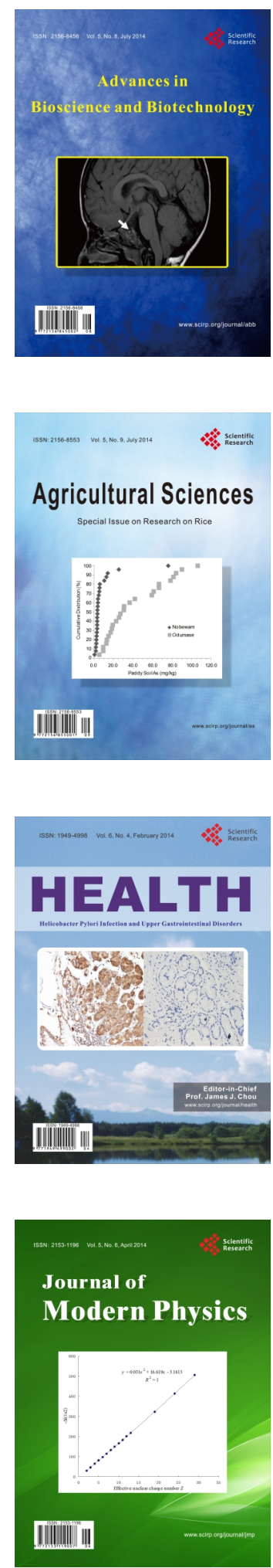
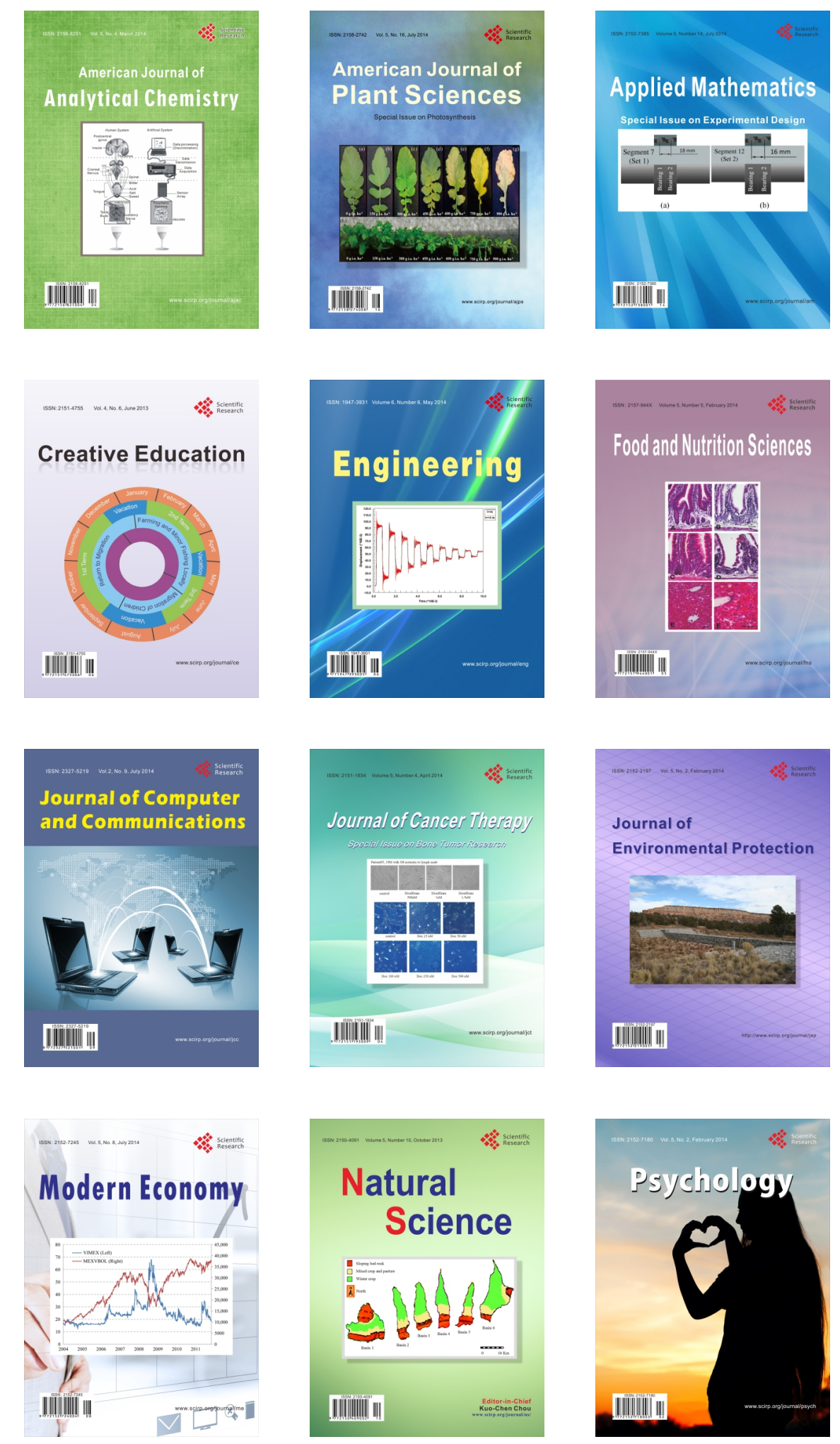